\title{
Carbon dioxide emissions from an Acacia plantation on peatland in Sumatra, Indonesia
}

\author{
J. Jauhiainen ${ }^{1}$, A. Hooijer ${ }^{2}$, and S. E. Page ${ }^{3}$ \\ ${ }^{1}$ Department of Forest Sciences, University of Helsinki, P.O. Box 27, 00014 University of Helsinki, Helsinki, Finland \\ ${ }^{2}$ Deltares, P.O. Box 177, 2600 MH Delft, The Netherlands \\ ${ }^{3}$ Department of Geography, University of Leicester, Leicester LE1 7RH, UK
}

Correspondence to: J. Jauhiainen (jyrki.jauhiainen@helsinki.fi )

Received: 1 July 2011 - Published in Biogeosciences Discuss.: 12 August 2011

Revised: 4 January 2012 - Accepted: 13 January 2012 - Published: 1 February 2012

\begin{abstract}
Peat surface $\mathrm{CO}_{2}$ emission, groundwater table depth and peat temperature were monitored for two years along transects in an Acacia plantation on thick tropical peat ( $>4 \mathrm{~m}$ ) in Sumatra, Indonesia. A total of 2300 emission measurements were taken at 144 locations, over a 2 year period. The autotrophic root respiration component of $\mathrm{CO}_{2}$ emission was separated from heterotrophic emission caused by peat oxidation in three ways: (i) by comparing $\mathrm{CO}_{2}$ emissions within and beyond the tree rooting zone, (ii) by comparing $\mathrm{CO}_{2}$ emissions with and without peat trenching (i.e. cutting any roots remaining in the peat beyond the tree rooting zone), and (iii) by comparing $\mathrm{CO}_{2}$ emissions before and after Acacia tree harvesting. On average, the contribution of autotrophic respiration to daytime $\mathrm{CO}_{2}$ emission was $21 \%$ along transects in mature tree stands. At locations $0.5 \mathrm{~m}$ from trees this was up to $80 \%$ of the total emissions, but it was negligible at locations more than $1.3 \mathrm{~m}$ away. This means that $\mathrm{CO}_{2}$ emission measurements well away from trees were free of any autotrophic respiration contribution and thus represent only heterotrophic emissions. We found daytime mean annual $\mathrm{CO}_{2}$ emission from peat oxidation alone of $94 \mathrm{tha}^{-1} \mathrm{y}^{-1}$ at a mean water table depth of $0.8 \mathrm{~m}$, and a minimum emission value of $80 \mathrm{tha}^{-1} \mathrm{y}^{-1}$ after correction for the effect of diurnal temperature fluctuations, which may result in a $14.5 \%$ reduction of the daytime emission. There is a positive correlation between mean long-term water table depth and peat oxidation $\mathrm{CO}_{2}$ emission. However, no such relation is found for instantaneous emission/water table depth within transects and it is clear that factors other than water table depth also affect peat oxidation and total $\mathrm{CO}_{2}$ emissions. The increase in the temperature of the surface peat due to plantation establishment may explain over $50 \%$ of peat oxidation emissions. Our study sets a standard
\end{abstract}

for greenhouse gas flux studies from tropical peatlands under different forms of agricultural land management. It is the first to purposefully quantify heterotrophic $\mathrm{CO}_{2}$ emissions resulting from tropical peat decomposition by separating these from autotrophic emissions. It also provides the most scientifically- and statistically-rigorous study to date of $\mathrm{CO}_{2}$ emissions resulting from anthropogenic modification of this globally significant carbon rich ecosystem. Our findings indicate that past studies have underestimated emissions from peatland plantations, with important implications for the scale of greenhouse gas emissions arising from land use change, particularly in the light of current, rapid agricultural conversion of peatlands in the Southeast Asian region.

\section{Introduction}

Lowland peatlands in Southeast Asia cover 24.8 million hectares (Mha), which is $56 \%$ of the tropical and $6 \%$ of the global peatland area (Page et al., 2011). Their high carbon density gives rise to a large regional peat carbon store of $68.5 \mathrm{Gt}$, equivalent to $77 \%$ of the tropical and $11-14 \%$ of the global peat carbon store (Page et al., 2011). These peat deposits are formed and maintained by continuous organic matter inputs from tropical evergreen forests under waterlogged conditions. Since 1990, 5.1 Mha of the total 15.5 Mha of peatland in Peninsular Malaysia and the islands of Borneo and Sumatra have been deforested, drained and burned while most of the remaining peat swamp forest has been logged intensively (Langner and Siegert, 2009; Miettinen and Liew, 2010). Over the same period, the area of unmanaged secondary peat swamp forest doubled to nearly a quarter of all peatlands, whilst industrial oil palm and pulpwood (Acacia) 
plantations expanded dramatically from 0.3 Mha to $2.3 \mathrm{Mha}$, an increase from 2 to $15 \%$ of the total peatland area. By 2008, only $10 \%$ of the peatlands of Peninsular Malaysia, Borneo and Sumatra remained in an intact or slightly degraded condition (Miettinen and Liew, 2010). This high rate of land use change and associated increased rate of organic matter oxidation in disturbed and drainage impacted peat, has received increasing attention in recent years in both scientific and policy fora (e.g. Fargione et al., 2008; Rieley et al., 2008; Page et al., 2009; Couwenberg et al., 2010; Edwards et al., 2010; Hooijer et al., 2010; Murdiyarso et al., 2010; Koh et al., 2011). Hence, there is a strong interest in quantifying accurately carbon losses and greenhouse gas emissions from drained tropical peatlands as part of the wider debate on the impacts of tropical land use change on climate change processes. The carbon dynamics of tropical peatland involve $\mathrm{CO}_{2}$ uptake via photosynthesis and losses through autotrophic respiration of vegetation, $\mathrm{CO}_{2}$ and $\mathrm{CH}_{4}$ emissions from soil organic matter decomposition (heterotrophic respiration), and fluvial exports of dissolved and particulate organic carbon (DOC and POC) (e.g. Jauhiainen et al., 2005, 2008; Rieley et al., 2008; Moore et al., 2011). The quantity of methane $\left(\mathrm{CH}_{4}\right)$ emitted from anaerobic peat decomposition is small and its effect on atmospheric processes is much less than concurrent $\mathrm{CO}_{2}$ emissions (Hadi et al., 2005; Jauhiainen et al., 2005, 2008, 2012). In peat swamp forest the difference between $\mathrm{CO}_{2}$ sequestered and that lost through autotrophic and heterotrophic respiration is stored as structural carbon in tree biomass and accumulated as peat. Unfortunately, most data used to assess the scale of peat carbon losses from drainage-impacted tropical peatlands are confusing and contradictory and the literature on gaseous carbon emissions has been questioned for not quantifying separately autotrophic $\mathrm{CO}_{2}$ emissions from tree roots and heterotrophic emissions from peat oxidation (c.f. meta-analyses by Couwenberg et al., 2010; Hooijer et al., 2010). Two principal methods have been employed, namely closed chamber monitoring (real time) of gaseous $\mathrm{CO}_{2}$ emissions from the peat surface, and measurement of the lowering of the peat surface as a result of subsidence over time combined with information on peat carbon concentration and bulk density (Couwenberg et al., 2010; Hooijer et al., 2012). Carbon loss estimates based on the latter approach have been hampered by small numbers of measurements, incomplete field information (inadequacy and inconsistency of monitoring) and a lack of reference data on peat characteristics that would enable accurate calculation of carbon loss rates from subsidence. Consequently, most published estimates of carbon losses are derived from peat surface $\mathrm{CO}_{2}$ emission measurements obtained using the closed-chamber method. Even for this method, however, there are fewer than ten peer-reviewed publications presenting $\mathrm{CO}_{2}$ emissions data under monitored hydrological conditions in SE Asian peatlands (Inubushi et al., 2003; Furukawa et al., 2005; Hadi et al., 2005; Jauhiainen et al., 2005, 2008; Melling et al., 2005; Ali et al.,
Table 1. Main characteristics of the peat at the $\mathrm{CO}_{2}$ monitoring transects.

\begin{tabular}{lccc}
\hline & \multicolumn{3}{c}{ Peat } \\
\cline { 2 - 4 } Transect & $\begin{array}{c}\text { Depth } \\
(\mathrm{m})\end{array}$ & $\begin{array}{c}\mathrm{BD}^{*} \\
\left(\mathrm{~g} \mathrm{~cm}^{-3}\right)\end{array}$ & $\begin{array}{c}\text { Ash content* } \\
(\% \text { of dw })\end{array}$ \\
\hline A & $4.1-4.7$ & $0.11 \pm 0.01$ & $0.29 \pm 0.11$ \\
B & $7.8-9.0$ & $0.12 \pm 0.02$ & $2.61 \pm 1.37$ \\
C, D & $4.6-5.1$ & $0.08 \pm 0.03$ & $0.15 \pm 0.10$ \\
E & $5.1-5.5$ & $0.07 \pm 0.01$ & $0.08 \pm 0.02$ \\
F & $7.9-9.5$ & $0.06 \pm 0.01$ & $0.51 \pm 0.24$ \\
G, H & $5.0-6.2$ & $0.06 \pm 0.01$ & $0.19 \pm 0.05$ \\
\hline
\end{tabular}

* Mean \pm SD at $30-50 \mathrm{~cm}$ horizon from the peat surface $(n=3-9)$.

2006; Hirano et al., 2009). None of these has separated the contribution of $\mathrm{CO}_{2}$ released in root respiration from total $\mathrm{CO}_{2}$ emissions, making it impossible to determine $\mathrm{CO}_{2}$ emissions arising solely from peat decomposition, i.e. heterotrophic emissions. Further complications are caused by poorly described methods, inconsistent data collection procedures and high variation in the size of data sets, all of which prevent exact and meaningful comparison of results. There is, therefore, an urgent need for tropical peat surface emissions data that quantify accurately the separate components of $\mathrm{CO}_{2}$ emissions and provide sufficient information on their temporal and spatial variation.

The focus of this paper is on the $\mathrm{CO}_{2}$ emissions arising from peat decomposition following conversion of peat swamp forest to industrial plantation of Acacia pulp wood trees. Our aim is to quantify heterotrophic $\mathrm{CO}_{2}$ emissions across a range of conditions and obtain improved understanding of the drivers of peat oxidation. Based on daytime gas flux monitoring we assessed the effects on emissions of (i) land cover type and plantation tree growth stage and (ii) water table depth on both total (heterotrophic plus autotrophic) $\mathrm{CO}_{2}$ emissions and emissions caused by peat oxidation alone (heterotrophic). We determined the relative contributions of autotrophic and heterotrophic emissions to total emissions. Based on our field data and values from the literature, we also investigated the effect of temperature on $\mathrm{CO}_{2}$ emissions in tree stands at different stages of canopy closure.

\section{Site characteristics and methods}

\subsection{Site location and sampling procedure}

The study area is in an Acacia (pulp wood) plantation on peatland in the Kampar Peninsula, Riau Province, Sumatra, Indonesia $\left(\mathrm{N} 0^{\circ} 26^{\prime} 06.9^{\prime \prime}, \mathrm{E} 101^{\circ} 53^{\prime} 01.4^{\prime \prime}\right)$. This part of eastern Sumatra has an average annual rainfall of around $2500 \mathrm{~mm}$ and average daytime air temperature around $28^{\circ} \mathrm{C}$. The Kampar Peninsula contains contiguous peat deposits of 

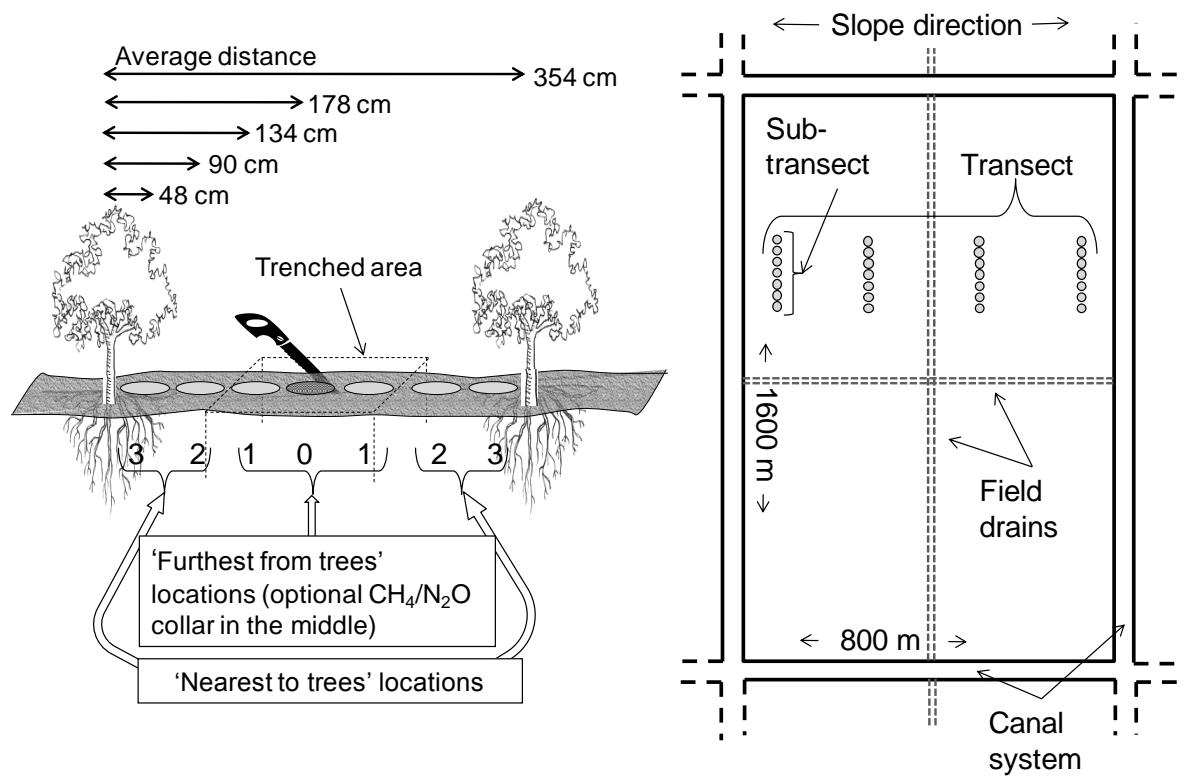

Fig. 1. Outline of $\mathrm{CO}_{2}$ emission monitoring location arrangement at a sub-transect, and of a transect in a tree growing unit.

Table 2. Tree stand age characteristics (months) and average water table characteristics ( $\mathrm{m}$ from the peat surface) at the $\mathrm{CO}_{2} \mathrm{monitoring}$ transects over the two year monitoring period.

\begin{tabular}{|c|c|c|c|c|c|c|c|c|c|c|c|c|c|c|c|}
\hline & \multicolumn{7}{|c|}{ Tree stand age (months) } & \multicolumn{8}{|c|}{ Water table depth (m) } \\
\hline & A & B & $\mathrm{C}$ & $\mathrm{D}$ & $\mathrm{E}$ & $\mathrm{F}$ & $\mathrm{G}, \mathrm{H}$ & A & $\mathrm{B}$ & $\mathrm{C}$ & $\mathrm{D}$ & $\mathrm{E}$ & $\mathrm{F}$ & $\mathrm{G}^{*}$ & $\mathrm{H}$ \\
\hline Mean & 31.2 & 32.6 & 46.2 & 1.3 & 6.0 & 7.1 & 12.2 & 0.93 & 0.77 & 1.06 & 0.71 & 0.72 & 0.84 & 0.43 & 0.92 \\
\hline SD & 6.1 & 4.4 & 6.0 & 2.4 & 0.8 & 3.4 & 2.7 & 0.28 & 0.16 & 0.33 & 0.25 & 0.22 & 0.14 & 0.12 & 0.16 \\
\hline Range & 17 & 17 & 20 & 13 & 2 & 12 & 8 & 1.28 & 0.90 & 1.55 & 1.26 & 0.94 & 0.67 & 0.55 & 0.60 \\
\hline Min. & 24 & 26 & 40 & 0 & 5 & -2 & 8 & 0.30 & 0.31 & 0.41 & 0.07 & 0.26 & 0.55 & 0.17 & 0.60 \\
\hline Max. & 41 & 43 & 60 & 13 & 7 & 10 & 16 & 1.58 & 1.21 & 1.96 & 1.20 & 1.20 & 1.22 & 0.72 & 1.20 \\
\hline$\%$ ile 25 & 26 & 29 & 41 & 0 & 5 & 6 & 10 & 0.72 & 0.67 & 0.83 & 0.58 & 0.59 & 0.73 & 0.34 & 0.81 \\
\hline$\%$ ile 50 & 28 & 33 & 43 & 0 & 6 & 9 & 13 & 0.90 & 0.76 & 1.04 & 0.69 & 0.73 & 0.83 & 0.43 & 0.97 \\
\hline \%ile 75 & 38 & 35 & 52 & 2 & 7 & 9 & 14 & 1.13 & 0.87 & 1.26 & 0.90 & 0.86 & 0.94 & 0.52 & 1.04 \\
\hline Cycle & $1 \mathrm{st}$ & $1 \mathrm{st}$ & $1 \mathrm{st}$ & 2nd & 2nd & 2nd & 2nd & & & & & & & & \\
\hline
\end{tabular}

* At G transect water table was maintained closer to surface than is normal in the plantation area.

around 700000 ha. Prior to clearance of $\sim 160000$ ha for plantation development from the year 2000 onwards, the area was peat swamp forest. The area was not affected by fire immediately prior to, during, or after land use change.

Data were collected over a 24-month period (April 2007 to April 2009) along 8 transects, A-H, located on one large peat dome on which peat thickness ranged from $4-9 \mathrm{~m}$ (average $6 \mathrm{~m}$ ) (Table 1). The plantation area is drained by a rectangular system of canals at $800 \mathrm{~m}$ intervals (excluding field drains). The transects, $700 \mathrm{~m}$ long and up to $28 \mathrm{~km}$ apart, were located in different locations on the peat dome at low altitudes (below $11 \mathrm{~m}$ a.s.l.) and were positioned perpendicular to drainage canals (Fig. 1). Each transect consisted of either two $(\mathrm{C}, \mathrm{D}, \mathrm{G}, \mathrm{H})$ or four $(\mathrm{A}, \mathrm{B}, \mathrm{E}, \mathrm{F})$ sub-transects along which monitoring locations were situated. The subtransects were located at $200 \mathrm{~m}$ intervals from each other, with the first being $100 \mathrm{~m}$ from the nearest canal. They were positioned between tree rows, which were $\sim 3.5 \mathrm{~m}$ apart. The peat surface along all transects was almost flat, and microtopographic differences between emission monitoring locations $(5 \pm 11 \mathrm{~cm}$ to $9 \pm 7 \mathrm{~cm})$ were not significant; the maximum peat surface height difference was only $31 \mathrm{~cm}$ between measurement locations along all 8 transects.

\subsection{Acacia tree stand characteristics along transects}

Stands of plantation trees along transects consisted of both 1 st and 2nd rotation cycles (Table 2); one rotation being $\sim 5$ years from planting to harvest. Monitoring transects 
Table 3. Temperatures (mean $\pm \mathrm{SD}$ ) of air close to the peat surface, and at depths of 5,10 , and $60 \mathrm{~cm}$ into the peat based on manual measurements at daytime during $\mathrm{CO}_{2}$ flux monitoring and diurnally collected logger data.

\begin{tabular}{|c|c|c|c|c|c|c|}
\hline & \multicolumn{6}{|c|}{ Temperature $\left({ }^{\circ} \mathrm{C}\right)$ at transects } \\
\hline & \multicolumn{4}{|c|}{ Manual measurement* } & \multicolumn{2}{|c|}{ Logger data } \\
\hline & \multicolumn{4}{|c|}{ Daytime } & Daytime & Diurnal \\
\hline Position & A & $\mathrm{B}$ & $\mathrm{C}$ & $\mathrm{D}$ & B & B \\
\hline Air & $30.9 \pm 2.7$ & $28.9 \pm 2.1$ & $30.2 \pm 1.7$ & $33.0 \pm 3.2$ & $29.7 \pm 2.9$ & $26.7 \pm 2.9$ \\
\hline $5 \mathrm{~cm}$ & $29.2 \pm 2.3$ & $28.2 \pm 2.0$ & $28.6 \pm 1.4$ & $30.5 \pm 2.5$ & $27.8 \pm 1.6$ & $26.5 \pm 1.6$ \\
\hline $10 \mathrm{~cm}$ & $28.9 \pm 2.2$ & $28.2 \pm 1.9$ & $28.5 \pm 1.6$ & $29.4 \pm 2.1$ & $27.1 \pm 1.1$ & $27.0 \pm 1.2$ \\
\hline \multirow[t]{2}{*}{$60 \mathrm{~cm}$} & $31.3 \pm 2.6$ & $29.7 \pm 1.3$ & $30.9 \pm 0.9$ & $30.6 \pm 1.4$ & $28.5 \pm 0.6$ & $28.5 \pm 0.6$ \\
\hline & $\mathrm{E}$ & $\mathrm{F}$ & $\mathrm{G}$ & $\mathrm{H}$ & $\mathrm{H}$ & $\mathrm{H}$ \\
\hline Air & $36.9 \pm 2.3$ & $31.0 \pm 3.2$ & $34.1 \pm 3.8$ & $33.2 \pm 2.5$ & $32.6 \pm 3.7$ & $26.9 \pm 4.2$ \\
\hline $5 \mathrm{~cm}$ & $31.9 \pm 1.5$ & $29.3 \pm 2.2$ & $33.3 \pm 3.6$ & $32.6 \pm 2.6$ & $28.9 \pm 1.8$ & $27.3 \pm 2.0$ \\
\hline $10 \mathrm{~cm}$ & $30.3 \pm 1.6$ & $28.9 \pm 1.7$ & $33.1 \pm 3.5$ & $32.3 \pm 2.7$ & $27.9 \pm 1.0$ & $28.2 \pm 1.2$ \\
\hline $60 \mathrm{~cm}$ & $31.9 \pm 1.4$ & $30.7 \pm 1.1$ & $33.5 \pm 3.1$ & $33.4 \pm 2.0$ & $29.9 \pm 0.3$ & $29.9 \pm 0.4$ \\
\hline
\end{tabular}

* Daytime mean peat temperature at $5 \mathrm{~cm}$ depth is $30.5^{\circ} \mathrm{C}$ for all transects $(\mathrm{A}-\mathrm{H}), 28.7^{\circ} \mathrm{C}$ for transects $\mathrm{A}-\mathrm{C}$, and $31.5^{\circ} \mathrm{C}$ for transects $\mathrm{D}-\mathrm{H}$.

included recently harvested sites with bare peat through to closed canopy sites with mature trees. The usual plantation tree species was Acacia crassicarpa, with the exception of transect $\mathrm{G}$ where it was Melaleuca sp. Based on field observations, three plantation cycle stages were identified: (1) "open" areas including recently harvested areas and young plantations with trees up to 6 months old with an open canopy; (2) "immature" stands with a closing or closed canopy of 7-30 month old trees, and (3) "mature" closed canopy stands of 30 month to 5 year old trees. Descriptions of tree stand characteristics during the 2 year monitoring period are provided in Table 2. Transects D, E and F were located in "open" and "immature" stands; transects G and $\mathrm{H}$ were in the younger end of the "immature" tree growth stage; transects A and B were in the older end of the "immature" and "mature" growth stage; and C was in the "mature" growth stage (Table 2, Fig. 2).

\subsection{Measurement of peat characteristics}

\subsubsection{Groundwater table depth}

The depth of the water table below the peat surface was monitored monthly or quarterly, at the same locations and times as $\mathrm{CO}_{2}$ emissions, in perforated PVC tubes inserted in the peat surface along the sub-transects.

\subsubsection{Bulk density and ash content}

Peat samples for determination of bulk density and ash content were collected following the method explained in Hooijer et al. (2012).

\subsubsection{Peat temperature}

Peat temperatures were measured, using a digital thermocouple (Eutech, EcoScan) equipped with a K-type probe, at the same times and positions as the $\mathrm{CO}_{2}$ emissions and water table measurements. Daytime temperature was measured above the peat surface and at depths of 5, 10, 20 and $30 \mathrm{~cm}$ in the peat. Towards the end of the study, temperature was also determined at depths of 40, 50 and $60 \mathrm{~cm}$. Temperatures were measured close to mid-day (average time 11:33) with $50 \%$ of the observations made between 10:28 and 13:14. In order to investigate diurnal fluctuations, temperatures in the peat profile were recorded using Thermochron ${ }^{\circledR}$ data loggers at 2-hourly intervals at five peat depths (between 5 and $60 \mathrm{~cm}$ ) along transect B (closed canopy Acacia, 31-36 months old) and transect $\mathrm{H}$ (immature Acacia, 5-11 months old) during May-October 2008. The key temperature characteristics of the transects are shown in Table 3.

\section{$2.4 \mathrm{CO}_{2}$ emission monitoring}

$\mathrm{CO}_{2}$ emissions were measured along arrays of 7 regularlyspaced $(\sim 0.5 \mathrm{~m})$ gas flux monitoring locations between two adjacent living trees (Fig. 1), assuming that emissions furthest from the tree rooting zone would have a smaller autotrophic component in comparison to those nearest to trees.

Surface peat $\mathrm{CO}_{2}$ emissions were measured by using a portable infrared gas analyzer EGM-4 connected to an SRC1 respiration chamber unit (PP Systems, Hitchin, United Kingdom). In order to increase the measurement area, the standard $10 \mathrm{~cm}$ cover of the SRC-1 unit chamber was replaced by a $30 \mathrm{~cm}$ diameter one. During measurements, the chamber was placed securely over the peat surface and $\mathrm{CO}_{2}$ 
Table 4. Mean daytime measured heterotrophic respiration $\mathrm{CO}_{2}$ emissions (in "furthest from trees" locations) and total soil $\mathrm{CO}_{2}$ emissions ("nearest to trees" locations) and the related mean water table depths at the monitoring transects.

\begin{tabular}{|c|c|c|c|c|c|c|c|c|c|c|}
\hline \multirow[t]{2}{*}{$\begin{array}{l}\text { Transect } \\
\text { code }\end{array}$} & \multirow[t]{2}{*}{$\begin{array}{l}\text { Peat surface } \\
\text { emission type }\end{array}$} & \multirow[t]{2}{*}{$n$} & \multicolumn{3}{|c|}{$\begin{array}{c}\mathrm{CO}_{2} \\
\left(\mathrm{mg} \mathrm{m}^{-2} \mathrm{~h}^{-1}\right)\end{array}$} & \multicolumn{3}{|c|}{$\begin{array}{l}\text { Water table depth } \\
(\mathrm{m})\end{array}$} & \multirow[t]{2}{*}{$\begin{array}{l}\text { p-value } \\
\mathrm{CO}_{2}\end{array}$} & \multirow[t]{2}{*}{$\begin{array}{l}\text { p-value } \\
\text { WD }\end{array}$} \\
\hline & & & Mean & SE & SD & Mean & SE & SD & & \\
\hline \multirow[b]{2}{*}{ A } & Heterotrophic & 158 & 1128 & 23 & 292 & 0.92 & 0.02 & 0.27 & \multirow[b]{2}{*}{$<0.001$} & \multirow[b]{2}{*}{ ns } \\
\hline & Total & 284 & 1758 & 38 & 649 & 0.94 & 0.02 & 0.28 & & \\
\hline \multirow[b]{2}{*}{$\mathrm{B}^{*}$} & Heterotrophic & 192 & 1028 & 26 & 364 & 0.78 & 0.01 & 0.15 & \multirow[b]{2}{*}{$<0.001$} & \multirow[b]{2}{*}{$<0.005$} \\
\hline & Total & 270 & 1242 & 26 & 426 & 0.73 & 0.01 & 0.17 & & \\
\hline \multirow[b]{2}{*}{$\mathrm{C}$} & Heterotrophic & 140 & 1185 & 43 & 507 & 1.03 & 0.03 & 0.32 & \multirow[b]{2}{*}{ ns } & \multirow[b]{2}{*}{ ns } \\
\hline & Total & 222 & 1300 & 40 & 596 & 1.08 & 0.02 & 0.33 & & \\
\hline \multirow[t]{2}{*}{$\mathrm{D}^{*}$} & Heterotrophic & 350 & 903 & 14 & 253 & 0.69 & 0.01 & 0.25 & \multirow{2}{*}{$<0.001$} & \multirow{2}{*}{$<0.01$} \\
\hline & Total & 71 & 705 & 38 & 319 & 0.78 & 0.03 & 0.24 & & \\
\hline \multirow[b]{2}{*}{$\mathrm{E}$} & Heterotrophic & 34 & 799 & 67 & 392 & 0.75 & 0.04 & 0.23 & \multirow[b]{2}{*}{ ns } & \multirow[b]{2}{*}{ ns } \\
\hline & Total & 44 & 755 & 67 & 446 & 0.70 & 0.03 & 0.22 & & \\
\hline \multirow[b]{2}{*}{$\mathrm{F}$} & Heterotrophic & 74 & 1103 & 49 & 417 & 0.85 & 0.02 & 0.14 & \multirow[b]{2}{*}{$<0.001$} & \multirow[b]{2}{*}{ ns } \\
\hline & Total & 154 & 1366 & 39 & 480 & 0.84 & 0.01 & 0.14 & & \\
\hline \multirow[b]{2}{*}{ G } & Heterotrophic & 143 & 844 & 24 & 283 & 0.45 & 0.01 & 0.12 & \multirow[b]{2}{*}{ ns } & \multirow[b]{2}{*}{ ns } \\
\hline & Total & 30 & 887 & 49 & 271 & 0.36 & 0.02 & 0.09 & & \\
\hline \multirow[b]{2}{*}{$\mathrm{H}$} & Heterotrophic & 127 & 1584 & 44 & 496 & 0.93 & 0.01 & 0.16 & \multirow[b]{2}{*}{$<0.05$} & \multirow[b]{2}{*}{ ns } \\
\hline & Total & 29 & 1345 & 74 & 398 & 0.86 & 0.02 & 0.12 & & \\
\hline
\end{tabular}

${ }^{*}$ By accounting water table depth as covariate at B and D transects:

\begin{tabular}{lll|ll|l|l}
\hline B & Heterotrophic & 192 & 1019 & 29 & 0.75 & $<0.001$ \\
& Total & 270 & 1248 & 24 & & $<0.001$ \\
\hline \multirow{2}{*}{ D } & Heterotrophic & 350 & 904 & 14 & 0.70 & \\
\hline
\end{tabular}

concentrations were recorded automatically at $5 \mathrm{~s}$ intervals for a total incubation period of $81 \mathrm{~s}$ to ensure that readings were consistent and that the chambers were stable and did not leak. The $\mathrm{CO}_{2}$ emission rates were calculated from the linear change of gas concentration inside the closed chamber as a function of measurement time. Readings were rejected if nonlinear concentration changes were obtained during incubation, owing to leakage or peat disturbance. Readings taken near to damaged trees (wind thrown) were not included in the data set. Measurements were made 2-weekly to monthly unless there were problems of gaining access to the transects. In total, more than $2300 \mathrm{CO}_{2}$ emission measurements were obtained at 144 individual locations forming the sub-transects and transects (Table 4, Fig. 1). For the timing of measurements during the day see Sect. 2.3.3.

\subsection{Treatments to minimize $\operatorname{root} \mathrm{CO}_{2}$ emissions}

Soil $\mathrm{CO}_{2}$ emission was partitioned into autotrophic root respiration and heterotrophic peat oxidation components by using several methods. First, the presence of autotrophic $\mathrm{CO}_{2}$ emission sources was determined through pit observations, 
which indicated that the bulk of the Acacia root system, even near "mature" trees, was restricted to within less than a metre from the tree although, in some instances, a few roots close to the peat surface extended over a longer distance in mature stands. Very few roots were found at monitoring locations in the middle of sub-transects, and it could therefore be assumed that at such locations (i.e. $\geq 1.3 \mathrm{~m}$ from trees on average) respiration from tree roots was negligible (see Fig. 1). Secondly, monitoring locations were kept free from any herbaceous vegetation; however it should be noted that such vegetation was scarce or absent in most locations. Thirdly, during the last 6 months of monitoring the contribution of root respiration to total $\mathrm{CO}_{2}$ emission was tested experimentally along transects $\mathrm{B}, \mathrm{D}, \mathrm{G}$ and $\mathrm{H}$ by regular trenching (sawing) of the peat surface down to a depth of $0.5 \mathrm{~m}$ around the three central monitoring locations on each sub-transect (at least $\sim 1.3 \mathrm{~m}$ from trees, Fig. 1), which was the depth within which most lateral tree root growth occurred according to our pit observations. Finally, trees were felled along several transects, before (transects E, G, H) or during (transects D, F) the monitoring period, which allowed measurements also under conditions where live tree roots were guaranteed to be excluded (following harvesting) or, in very young plantation stands, where lateral growth of tree roots was negligible (see minimum tree age in Table 2).

Based on the measures taken in data collection outlined above and in subsequent data analysis (see Sect. 3.2), $\mathrm{CO}_{2}$ emission data obtained from the "furthest from trees" monitoring locations were defined as "heterotrophic emissions", and this expression is used in the results and discussion. The data from the "nearest to trees" locations include emissions from both roots and organic matter decomposition and hence "total soil respiration" is used for this emission in the results and discussion. Mean daytime autotrophic respiration was calculated by subtracting the mean of the $\mathrm{CO}_{2}$ emission measured at the "furthest from trees" locations from that of the "nearest to trees" locations, i.e. heterotrophic emission was subtracted from the total soil respiration emission for mature Acacia growth stages (data are based on Table 4).

\subsection{Statistical analyses}

The SPSS ${ }^{\mathrm{TM}}$ statistical package was used for descriptive and comparative statistical analyses of the data. The main statistical test was univariate analysis of variance (one-way ANOVA), run at the $95 \%$ confidence level.

\section{Results}

\subsection{Peat characteristics}

\subsubsection{Bulk density and ash content}

Characteristics of the upper peat layer were similar along most transects, with ranges of $0.06-0.12 \mathrm{~g} \mathrm{~cm}^{-3}$ (average
$0.09 \mathrm{~g} \mathrm{~cm}^{-3}$ ) and $0.08-2.20 \%$ (average $0.71 \%$ ), for bulk density and ash content, respectively (Table 1). This confirmed our observation that surface peat at all locations was fibric to hemic, with a very low mineral content, indicating the ombrotrophic nature of the peat.

\subsubsection{Groundwater table depth}

The average water table depth along all transects was about $0.8 \mathrm{~m}$ but there were considerable variations in time and space during the two-year monitoring period (Table 2). On average, the lowest water table during $\mathrm{CO}_{2}$ flux monitoring was at transect $\mathrm{C}$ (mean $1.06 \mathrm{~m}$, and $75 \%$ quartile upper limit at $1.04 \mathrm{~m}$ ). For transects $\mathrm{A}$ and $\mathrm{H}$ the water table depth mean was about $0.9 \mathrm{~m}$; along the F, D, B and E transects there were shallower drainage conditions with mean water table depths of between 0.84 and $0.70 \mathrm{~m}$. Transects $\mathrm{G}$ and $\mathrm{H}$ were located in a hydrology test site where water tables were maintained at distinctly different depths, i.e. the mean water table was $0.43 \mathrm{~m}$ at transect $\mathrm{G}$ and $0.92 \mathrm{~m}$ at transect $\mathrm{H}$.

$\mathrm{CO}_{2}$ emissions and water table depths as measured at "nearest to trees" and "furthest from trees" locations differed significantly only along transects B and D (Table 4). The potential role of water table depth difference on $\mathrm{CO}_{2}$ emission was tested by applying water table depth as a covariate in the analysis for these two transects, but the impact of water table depth difference on the emissions was found to be low (Table 4).

\subsubsection{Peat temperature}

The average daytime air temperature close to the peat surface was $33.6^{\circ} \mathrm{C}$ along transects in the open and young immature Acacia stages (transects D, E, F, G, H) and $30.0^{\circ} \mathrm{C}$ in closed canopy Acacia (transects A, B, C), (Table 3). At a depth of $5 \mathrm{~cm}$ below the peat surface, mean daytime temperatures were between $29.3^{\circ} \mathrm{C}$ and $33.0^{\circ} \mathrm{C}$ (mean $31.5^{\circ} \mathrm{C}$ ) in the open and young immature tree stands (transects $\mathrm{D}, \mathrm{E}$, $\mathrm{F}, \mathrm{G}, \mathrm{H}$ ) and between $28.2^{\circ} \mathrm{C}$ and $29.2^{\circ} \mathrm{C}$ (mean $28.7^{\circ} \mathrm{C}$ ) in closed canopy tree stands (transects A, B, C). Diurnal mean $(24 \mathrm{~h})$ and mean daytime (11:00 to $13: 00)$ peat temperatures at a depth of $5 \mathrm{~cm}$ differed by $1.3^{\circ} \mathrm{C}$ to $1.6^{\circ} \mathrm{C}$ along the closed canopy transect $\mathrm{B}$ and the open canopy transect $\mathrm{H}$, respectively. The difference between daytime and diurnal peat temperature averages rapidly diminished with peat depth, to $0.3^{\circ} \mathrm{C}$ at $10 \mathrm{~cm}$ depth. Data from both manual measurements and automated temperature loggers indicated comparable temperature differences. 


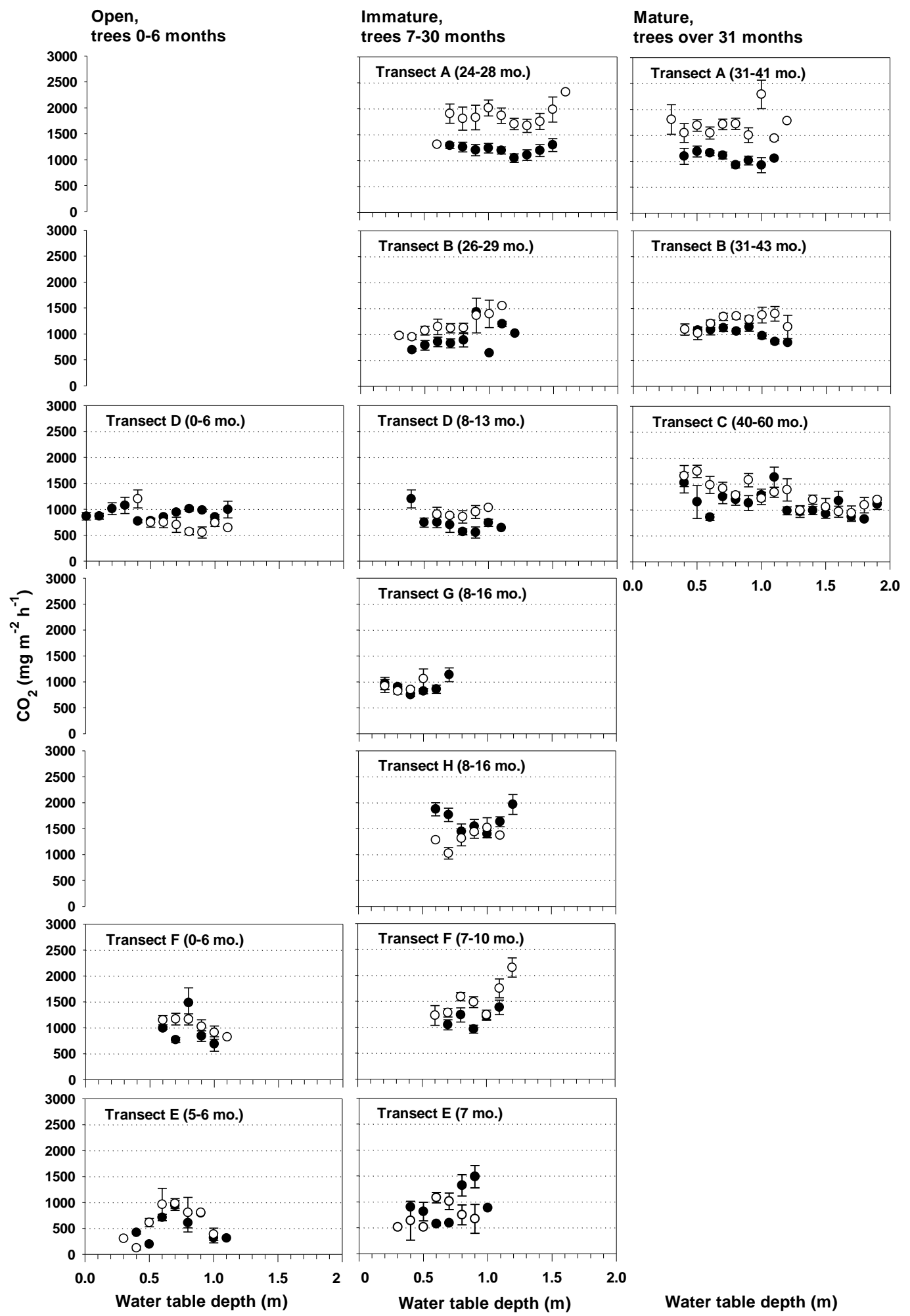

Fig. 2. Instantaneous daytime $\mathrm{CO}_{2}$ emissions (mean $\pm \mathrm{SE}$ ) at transects representing various tree growth stages using $10 \mathrm{~cm}$ wide water table depth classes. Mean $\mathrm{CO}_{2}$ emissions from heterotrophic respiration (•) and total soil $\mathrm{CO}_{2}$ emissions (o) are shown separately for each transect. Note that mean total $\mathrm{CO}_{2}$ emissions especially in open and young immature growth stages have non-existent or low autotrophic respiration and thus the two flux symbols may be of variable order. 

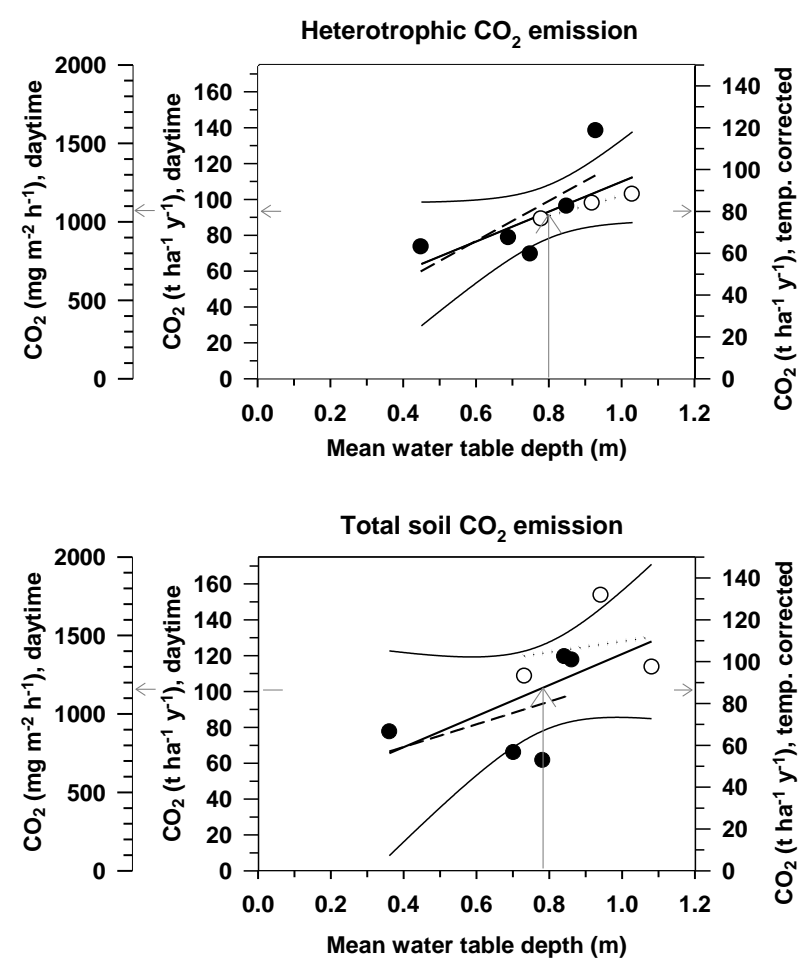

Fig. 3. Regression of mean peat surface $\mathrm{CO}_{2}$ emission from heterotrophic respiration (upper graph) and mean total soil $\mathrm{CO}_{2}$ emission (lower graph) at mean water table depths at the monitoring transects. Emission values provided in multiple units; daytime emission values $\left(\mathrm{mg} \mathrm{m}^{-2} \mathrm{~h}^{-1}, \mathrm{tha}^{-1} \mathrm{y}^{-1}\right)$ on the left axis, and temperature corrected emissions $\left(\mathrm{t} \mathrm{ha}^{-1} \mathrm{y}^{-1}\right)$ on the right axis. Linear regression lines for $\leq 16$ months old trees (o-symbol, dotted line), $\geq 24$ months old Acacia (•-symbol, dashed line), average (solid line), and $95 \%$ confidence limits (solid curves) for the combined data from 8 transects are provided. Arrows indicate regression mean emissions and water table depths.

\section{2 $\mathrm{CO}_{2}$ emissions}

No significant differences $(p>0.05)$ in $\mathrm{CO}_{2}$ emission were identified before and after trenching, at the "furthest from trees" measurement locations along the B, D, G and $\mathrm{H}$ transects that varied from "mature" to "open" during trenching operations. This confirmed that the tree roots were relatively localised around the bases of the trees. Since the data from emissions monitoring at both trenched and untreated locations did not differ, all data from the "furthest from trees" monitoring locations were combined for subsequent analyses. Daytime $\mathrm{CO}_{2}$ emissions data are summarised in Table 4 separated into those for total soil emissions and those for heterotrophic emissions.

The highest values for total soil respiration emissions were obtained along transects A, B, C, F and $\mathrm{H}$, three of which (A, $\mathrm{B}$ and $\mathrm{C}$ ) were "mature" plantations with average tree stand ages over 31 months. The lowest total emissions were ob- tained along the recently replanted and open transects $\mathrm{D}, \mathrm{E}$ and $\mathrm{G}$, with average tree stand ages below 13 months. In two of the three mature tree stands (transects A and B), mean total emissions were significantly higher than the heterotrophic emissions, at $56 \%$ and $21 \%$ respectively (Table 4). In the mature tree stands (A, B and C) the emission difference was even higher $(80 \%, 44 \%$ and $14 \%$ respectively) between individual monitoring locations at $\sim 50 \mathrm{~cm}$ distance from trees (location 3 in Fig. 1). In comparison to the values for heterotrophic $\mathrm{CO}_{2}$ emissions, however, the difference was only $28 \%, 4 \%$ and $1 \%$ respectively at a distance of $\sim 90 \mathrm{~cm}$ from trees (location 2 in Fig. 1). Along the other transects in the open and immature trees stands, the differences were in general smaller and either of the emission monitoring locations ("nearest to trees" or "furthest from trees") could result in the higher emission (Table 4).

Mean daytime autotrophic respiration, calculated as the emission difference between total and heterotrophic $\mathrm{CO}_{2}$ emissions, for the 1st rotation cycle closed canopy Acacia transects (A, B and C) varied between 115 and $630 \mathrm{mg}$ $\mathrm{CO}_{2} \mathrm{~m}^{-2} \mathrm{~h}^{-1}$ (data from Table 4). The highest average daytime autotrophic respiration at transect $\mathrm{A}$ was $36 \%$ of the total $\mathrm{CO}_{2}$ emission. For transects $\mathrm{B}$ and $\mathrm{C}$, the average autotrophic respiration emissions were about $17 \%$ and $9 \%$. The overall mean autotrophic respiration for these transects was $320 \mathrm{mgCO}_{2} \mathrm{~m}^{-2} \mathrm{~h}^{-1}$, which was $21 \%$ of the total $\mathrm{CO}_{2}$ emission.

\subsection{Relation between $\mathrm{CO}_{2}$ emissions, groundwater table depth and tree growth stage}

Analysis of datasets of instantaneous daytime $\mathrm{CO}_{2}$ emissions (both for total and heterotrophic emissions) and water table depth along individual transects yielded significant relations only for transects B, C, F, G and H. However, these relations were very different, and for the other transects no relation was evident at all (Fig. 2). Emission readouts in some of the data sub-sets in the $10 \mathrm{~cm}$ wide water table depth classes were either low in number or missing, which restricted comparisons between total and heterotrophic emissions in some conditions.

\subsection{Relation between $\mathrm{CO}_{2}$ emission and long-term average groundwater table depth}

In order to determine a possible effect of average long-term hydrological conditions on $\mathrm{CO}_{2}$ emissions, mean daytime emission rates over the two year monitoring period were tested against mean water table depths for each transect (Fig. 3, based on Table 4). For this analysis, monitoring transects were also separated into two categories, i.e. $\leq 16$ months and $\geq 24$ months old tree growth stages in order to determine if $\mathrm{CO}_{2}$ emissions differed following recent disturbance (harvesting) compared to the more stable conditions in maturing tree stands. 
There was a trend of reducing $\mathrm{CO}_{2}$ emission when the water table was closer to the peat surface (Fig. 3). Correlation between mean heterotrophic $\mathrm{CO}_{2}$ emission and mean water table depth, measured in the $\geq 24$ month old tree growth stages, was very high $\left(R^{2}=0.99\right)$. It was somewhat lower $\left(R^{2}=0.53\right)$ for combined open and $\leq 16$ month old tree growth stages. The total $\mathrm{CO}_{2}$ emission and mean water table depth relationship was unclear, however, with $R^{2}$ values below 0.22 obtained for the two growth stages used in the analysis (Fig. 3).

The relation between water table depth (in $\mathrm{m}$ ) and daytime $\mathrm{CO}_{2}$ emission (in $\mathrm{mg} \mathrm{m}^{-2} \mathrm{~h}^{-1}$ ) for all transects is described by the following linear regressions (95\% confidence limits):

For daytime heterotrophic $\mathrm{CO}_{2}$ emission: emission $=953.35 \times \mathrm{WTD}+309.07\left(R^{2}=0.47\right.$, $\mathrm{SE}=197)$

For daytime total $\mathrm{CO}_{2}$ emission: emission $=989.46 \times \mathrm{WTD}+391.79\left(R^{2}=0.34\right.$, $\mathrm{SE}=317)$

In this study, no significant relationship $\left(R^{2}\right.$ values from 0 to 0.02 ) was found between mean daytime heterotrophic and total $\mathrm{CO}_{2}$ emissions and peat temperature at all transects (Tables 3, 4). Several studies suggest temperature differences in peat impact on organic matter oxidation rates by ratio $Q_{10}=2$ (see Sect. 4.4 and 4.6 for details). An average difference between daytime and diurnal peat temperature at $5 \mathrm{~cm}$ depth of $1.45^{\circ} \mathrm{C}$ was found across the Acacia plantation growth stages. By applying temperature correction, based on diurnal surface peat temperature fluctuation and a $\mathrm{Q}_{10}$ value of 2, daytime $\mathrm{CO}_{2}$ emissions were subject to a $14.5 \%$ reduction. Presenting these temperature corrected emission values as scaled-up units $\left(\mathrm{tha}^{-1} \mathrm{y}^{-1}\right)$, the regressions for all transects are:

For temperature corrected heterotrophic $\mathrm{CO}_{2}$ emission: emission $=71.40 \times \mathrm{WTD}+23.15$ $\left(R^{2}=0.47, \mathrm{SE}=197\right)$

For temperature corrected total $\mathrm{CO}_{2}$ emission: emission $=74.11 \times \mathrm{WTD}+29.34\left(R^{2}=0.34\right.$, $\mathrm{SE}=317)$

\section{Discussion}

\subsection{Separation of peat surface $\mathrm{CO}_{2}$ emission sources}

Several measures taken in this study allowed us to separate heterotrophic and autotrophic $\mathrm{CO}_{2}$ emissions. The absence of tree roots and therefore of autotrophic respiration at locations "furthest from trees" was confirmed by (i) an observed lack of tree roots in control pits, (ii) a lack of effect of the "trenching" treatment on emissions, and (iii) the absence of a systematic reduction in emissions at locations where trees were harvested during the measurement period. Moreover, the finding that mean daytime total $\mathrm{CO}_{2}$ emission values for the most mature tree stands (transects $\mathrm{A}, \mathrm{B}$ and $\mathrm{C}$ ) were indeed considerably higher (by up to $80 \%, 44 \%$ and $14 \%$ respectively) at "nearest to trees" rather than at "furthest from trees" locations, demonstrated that the emission measurement method did measure autotrophic root respiration where it occurred, which further validated the method. We therefore conclude that it is indeed possible to measure emission that is largely or completely "root respiration free" in drained peatlands, by focusing on measurements well away from trees.

\subsection{The contribution of autotrophic respiration to the total $\mathrm{CO}_{2}$ emission}

Autotrophic root emissions contribute $35-45 \%$ to the total soil $\mathrm{CO}_{2}$ emissions in boreal peatlands (Nykänen et al., 1995; Silvola et al., 1996), and in non-tropical natural forest sites the contribution can be between $10 \%$ and $90 \%$, depending on vegetation type and season (Hanson et al., 2000). Somewhat similar percentages were found near trees in mature stands in our study (transects A, B and C), where we established that autotrophic respiration accounted for an average of $21 \%$ (36\%, $17 \%$ and $9 \%$, respectively) of total $\mathrm{CO}_{2}$ emissions. In immature tree stands of 7-16 months age (transects $\mathrm{E}, \mathrm{F}, \mathrm{G}$ and $\mathrm{H}$ ), however, the contribution of autotrophic respiration to total $\mathrm{CO}_{2}$ emission could not be calculated owing to very different emissions from the two monitoring locations (Table 4, Fig. 2), which is probably explained by the limited extent over which roots have extended in the short time since planting. Even in relatively mature tree stands, roots were observed to hardly go beyond $1 \mathrm{~m}$ from trees, which may be explained by the fact that these trees were still less than 4 years old. Their root systems, therefore, cannot be compared to those occurring in natural forest, where roots are known to extend for many metres from mature trees.

In recently harvested areas it is assumed that virtually all of the $\mathrm{CO}_{2}$ emission is from heterotrophic sources since the remaining tree roots are no longer functioning. At transects $\mathrm{D}, \mathrm{E}$ and $\mathrm{H}$, heterotrophic emission was higher than total emission, a difference that was statistically significant for transects D and H (Table 4). Disturbance and the uneven distribution of tree harvest residues on the peat surface may have contributed to the apparent anomaly at transect D (open, immediate post harvest and early immature stages of the plantation cycle). The reason for the emission difference at transect $\mathrm{H}$ (immature stage) is less clear, but relatively few measurements of total $\mathrm{CO}_{2}$ emission $(n=29$, Table 4$)$ were made at this site and this could have influenced this result. Analysis of instantaneous daytime $\mathrm{CO}_{2}$ emissions and water table depth classes resulted in a relatively modest relation (Sect. 3.3, Fig. 2) and the results based on these much smaller data sub-sets cannot be directly used to explain the 
general contribution of autotrophic respiration to the total $\mathrm{CO}_{2}$ emission.

The autotrophic respiration contribution of $21 \%$ to the total $\mathrm{CO}_{2}$ emission in mature tree stands is much lower than the previous values suggested for oil palm plantations on peatland, which range from $46 \%$ (Melling et al., 2007), to $36 \%$ (Murdiyarso et al., 2010) and 29\% (Hergoualc'h and Verchot, 2011). This difference may be caused by the fact that these earlier studies and reviews were based on very small numbers of measurements (at only one location in the case of Murdiyarso et al. (2010) referring to work by Melling et al., 2005), that were not specifically set up to separate autotrophic from heterotrophic $\mathrm{CO}_{2}$ emissions, i.e. these percentages proposed earlier are rough estimates of the autotrophic respiration contribution rather than actual measurements. In this study, the preciseness of the oxidation and total emission measurement data used in the calculation of root respiration can be considered to be much higher because the respective relative standard errors were low, at between $2 \%$ and $4 \%$ for mature tree stand sites (based on data in Table 4).

$\mathrm{CO}_{2}$ emission values from studies where the distance of the measurement location(s) from the nearest tree(s) is unknown (e.g. Melling et al., 2005), may be interpreted tentatively to represent $21 \%$ autotrophic and $79 \%$ heterotrophic emissions: the same percentages that we found in relatively mature Acacia plantation. There is no reason to believe that the percentage autotrophic respiration occurring in Acacia plantations differs much from the percentage expected in other types of plantation on peatland. Most of the root system of mature oil palms growing on deep peat in Jambi, Sumatra is concentrated in less than $1 \mathrm{~m}$ radius from the plants (A. Hooijer, unpublished data) similar to Acacia plantations. Considering that oil palms are generally planted further apart than Acacia trees (4-6 m compared to $3.5 \mathrm{~m}$ between tree rows), there will be relatively more peat surface where autotrophic respiration emission is negligible. Moreover, mature oil palm stands have heterotrophic $\mathrm{CO}_{2}$ emissions that are in the same range as those from mature Acacia tree stands, and they have similar water table depth and limited canopy cover (compared to natural conditions) (Hooijer et al., 2012). We therefore propose that the autotrophic respiration contribution to total soil $\mathrm{CO}_{2}$ emissions in Acacia plantations are also applicable to other peatlands that have been drained and converted to other types of peatland cultivation.

\subsection{Relation between $\mathrm{CO}_{2}$ emission and groundwater table depth}

When quantifying relations between $\mathrm{CO}_{2}$ emission and groundwater table depth, it must be borne in mind that water table depth per se does not control peat oxidation. Rather, it is a proxy for the moisture content of the peat above the water table, which has a direct effect on peat oxidation by in- fluencing oxygen availability in the pore space (Liyama and Osawa, 2010).

In peatlands with high groundwater tables and without controlled drainage, the relation between water table depth and soil moisture content is strong: both go up when it rains and down in dry periods. Jauhiainen et al. $(2005,2008)$ found that total $\mathrm{CO}_{2}$ emissions from undrained tropical peatland sites and those with unregulated drainage were lowest under water saturated conditions and increased as the water table fell during the dry season. In peatlands with low water tables and controlled permanent drainage such as Acacia plantations, however, this relation is far weaker. Only during major rainstorms is it certain that rainfall will reach the ground water table, as much of it is stored in the unsaturated zone above as moisture deficits created in preceding dry periods are replenished; under such conditions the peat moisture content may fluctuate over time with limited effect on water table depth (A. Hooijer, unpublished data). Moreover, peat water tables follow canal water levels that are managed to meet the operational plantation requirement of stable drainage depth, so that these can be controlled independently of weather conditions.

Considering the weak connection between water table depth and soil moisture content in the unsaturated peat where oxidation occurs, it is not surprising that the current study did not yield a significant relation between instantaneous $\mathrm{CO}_{2}$ emission and water table as measured on individual transects. If water tables had remained close to the peat surface for longer periods during this study, then heterotrophic emissions could possibly have changed faster relative to changes in water table depth and a nonlinear relationship between $\mathrm{CO}_{2}$ emission and water table depth might have been detected. The relationship between heterotrophic emissions from peat and water table depth has been found to be nonlinear at undrained sites and those with unregulated drainage, especially during periods when water table is close to the peat surface (e.g. Jauhiainen et al., 2005, 2008; Hirano et al., 2009). Owing to the permanent drainage required for optimal growth of Acacia in plantations on peat, these conditions did not occur along the study transects. However, the potential for lower emissions (and a non-linear relationship) can be seen in the data from transect $\mathrm{G}$ where water tables were kept permanently closer to the peat surface and heterotrophic emissions were lower than at the other transects. There are no published studies demonstrating the impact of rewetting on $\mathrm{CO}_{2}$ emissions on previously permanently drained tropical peat with which to compare this observation.

\subsection{The role of soil temperature in peat oxidation and $\mathrm{CO}_{2}$ emissions}

The rate of decomposition of organic matter in peatlands increases positively with increase in temperature (Lafleur et al., 2005; Minkkinen et al., 2007; Mäkiranta et al., 2009). In the tropics, diurnal and annual temperature fluctuations are 
relatively modest compared to northern peatlands. There is, however, a general temperature increase after deforestation and also an increase in diurnal temperature fluctuation in the surface peat and hence a likely increase in the rate of peat decomposition. In this study, a significant relationship was not found between mean daytime $\mathrm{CO}_{2}$ emission and mean daytime peat temperature at any of the transects $\left(R^{2}\right.$ values from 0 to 0.02 ), probably owing to the limited variation in daytime peat temperature along each (Table 3). For comparison, it would be important to obtain diurnal temperature data, preferably with simultaneous $\mathrm{CO}_{2}$ emission data, across clearly different sun exposure/canopy coverage conditions. In a previous study, however, a clear $\mathrm{CO}_{2}$ emission/temperature relationship for tropical peat was found, following 4 years of automated hourly monitoring of both variables in peat swamp forest, of a doubling of the rate of instantaneous in-situ peat $\mathrm{CO}_{2}$ emission over a temperature range of $5{ }^{\circ} \mathrm{C}$ (from $24^{\circ} \mathrm{C}$ to $29^{\circ} \mathrm{C}$ ) (including autotrophic respiration emissions) (Hirano et al., 2009). Moreover, longterm combined field and laboratory studies in the subtropical peatlands of the Everglades (Florida) showed that peat oxidation expressed as peat surface subsidence doubled with a $10^{\circ} \mathrm{C}$ increase in temperature (Stephens and Stewart, 1977). Similarly, $\mathrm{CO}_{2}$ emission rates from incubated surface samples of tropical peat from Sumatra were also found to double between $25^{\circ} \mathrm{C}$ and $35^{\circ} \mathrm{C}$ (Brady, 1997). Both Brady (1997) and Hirano et al. (2009) found that increase in temperature had a greater effect on $\mathrm{CO}_{2}$ emission rate than soil moisture or water table depth. In our study, we used this relation between temperature and $\mathrm{CO}_{2}$ emission to adjust $\mathrm{CO}_{2}$ measurements, obtained for higher daytime temperatures, to estimate diurnal average temperature conditions.

At a landscape-scale, the surface peat temperature in an intact peat swamp forest is lower and more constant than in deforested and developed tropical peatland (Jaya, 2007), not only because the forest floor is sheltered from direct sunlight but also because it is cooled by evaporation from the peat surface, which usually has a high water content. Average daytime peat temperature at a depth of $5 \mathrm{~cm}$ in peat swamp forest $\left(26.5^{\circ} \mathrm{C}\right)$ in Central Kalimantan is $2.9^{\circ} \mathrm{C}$ below the average air $\left(29.4^{\circ} \mathrm{C}\right)$ temperature inside the forest (Jauhiainen et al., 2008). After deforestation the amount of solar radiation reaching the peat surface increases and so does the temperature of the peat surface. In Central Kalimantan, the average daytime peat temperature at $5 \mathrm{~cm}$ depth is $4.4^{\circ} \mathrm{C}$ higher $\left(\right.$ at $29.9^{\circ} \mathrm{C}$ ) in open degraded peatland than in nearby non-drained forest $\left(25.5^{\circ} \mathrm{C}\right)$, while the air temperatures just above these peat surfaces are $32.4^{\circ} \mathrm{C}$ and $26.4^{\circ} \mathrm{C}$ respectively, a difference of $6^{\circ} \mathrm{C}$ (Jauhiainen et al., 2005, 2008). Jaya (2007) reports an even greater difference for elsewhere in Central Kalimantan, of $7.3^{\circ} \mathrm{C}$ between average diurnal surface peat temperature in an agricultural area $\left(30.2^{\circ} \mathrm{C}\right)$ and in adjacent, relatively intact forest $\left(22.9^{\circ} \mathrm{C}\right)$, while average daytime air temperatures are $33.4^{\circ} \mathrm{C}$ and $28.8^{\circ} \mathrm{C}$, respectively. In nearby heavily degraded forest, the average diurnal peat surface temperature and daytime air temperatures were $26.7^{\circ} \mathrm{C}$ and $30.4^{\circ} \mathrm{C}$, suggesting that even removing part of the canopy cover has a profound effect on peat surface and air temperatures. We conclude that the average temperature of surface peat under intact tropical forest cover is around $25^{\circ} \mathrm{C}$ at most, a value that we used in further calculations.

In this study, average daytime temperatures of peat and air in the Acacia plantation were similar to those in degraded peatland in Kalimantan. Average peat temperature at $5 \mathrm{~cm}$ depth was between $29.3{ }^{\circ} \mathrm{C}$ and $33.3^{\circ} \mathrm{C}$ (mean $31.5^{\circ} \mathrm{C}$ ) in open areas and from $28.2^{\circ} \mathrm{C}$ to $29.2^{\circ} \mathrm{C}$ (mean $30^{\circ} \mathrm{C}$ ) in closed canopy Acacia tree stands, and respective mean air temperatures were $33.6^{\circ} \mathrm{C}$ and $30^{\circ} \mathrm{C}$. It was likely that these temperatures had increased considerably since deforestation and drainage. If we assume the same original surface peat temperature of $25^{\circ} \mathrm{C}$ that was reported for natural peat swamp forest in Central Kalimantan (Jaya, 2007), then the temperature of the surface peat would have increased by $5.6^{\circ} \mathrm{C}$.

\section{5 $\mathrm{CO}_{2}$ emission rates and long-term, average groundwater table}

The means of the water table depths along each transect throughout the entire study period (i.e. long-term water table depth) showed a strong relationship with long-term mean heterotrophic respiration $\mathrm{CO}_{2}$ emissions (Fig. 3). $\mathrm{CO}_{2}$ emission rates along the transects were lower at higher water table depths (i.e. when the water table was nearer to the surface). A similar $\mathrm{CO}_{2}$ emission/water table depth relationship was found for the unplanted and recently planted $(\leq 16$ month old) transects and for those with older ( $\geq 24$ month old) trees. The highest regression $R^{2}$-value (0.99) was for the mature tree growth stage, which represented comparatively constant environmental conditions after several years had elapsed following harvesting and re-planting operations, and where the closed canopy provided relatively stable microclimatic conditions at the peat surface.

As the $\mathrm{CO}_{2}$ emission means were based on 2 years of data collected intensively from a relatively large area (Table 4), the values could be used to quantify annual emissions for the entire plantation. The overall daytime mean $( \pm$ SE) heterotrophic respiration emission derived by regression (Fig. 3) was $93.9 \pm 17.2 \mathrm{tCO}_{2} \mathrm{ha}^{-1} \mathrm{y}^{-1}\left(1072 \pm 197 \mathrm{mg} \mathrm{m}^{-2} \mathrm{~h}^{-1}\right)$ at $0.8 \mathrm{~m}$ water table depth. Other studies on permanently drained peat, albeit with relatively few measurements over shorter periods and without measures to quantify the contribution of autotrophic respiration, have provided emissions of $201 \mathrm{mg} \mathrm{m}^{-2} \mathrm{~h}^{-1}$ (water table depth $0.07 \mathrm{~m}$ ) on a taro field (Chimner and Ewel, 2004), $733 \mathrm{mg} \mathrm{m}^{-2} \mathrm{~h}^{-1}$ (water table depth $0.24 \mathrm{~m}$ ) on a cassava field (Furukawa et al., 2005), $504 \mathrm{mg} \mathrm{m}^{-2} \mathrm{~h}^{-1}$ (water table depth $0.27 \mathrm{~m}$ ) under sago and $693 \mathrm{mg} \mathrm{m}^{-2} \mathrm{~h}^{-1}$ (water table depth $0.60 \mathrm{~m}$ ) under oil palm (Melling et al., 2005). Although most of these mean $\mathrm{CO}_{2}$ emissions (op. cit.) were obtained at water table depths 
less than those recorded in this study, an extended regression line to water table depths of $0.2 \mathrm{~m}$ and $0.3 \mathrm{~m}$ (Fig. 3) would result in a similar $\mathrm{CO}_{2}$ emission range from 502 to $597 \mathrm{mg} \mathrm{CO}_{2} \mathrm{~m}^{-2} \mathrm{~h}^{-1}$.

The mean daytime heterotrophic respiration emission from this study of $\sim 94 \mathrm{t} \mathrm{CO}_{2} \mathrm{ha}^{-1} \mathrm{y}^{-1}$ at $0.8 \mathrm{~m}$ drainage depth (Fig. 3), is higher than reported in most other studies that have used subsidence measurements, as presented in recent meta-analyses (Couwenberg et al., 2010; Hooijer et al., 2010). One explanation for this may be that this value is based on daytime $\mathrm{CO}_{2}$ flux measurements, which may result in an overestimate because peat temperatures vary diurnally. This emission value can therefore be considered a maximum, which should be moderated for daytime temperature and emission both being above the daily average.

\subsection{Correcting $\mathrm{CO}_{2}$ emissions for temperature effect}

In this study, we calculated the potential impact of diurnal peat temperature differences on heterotrophic respiration rates on the basis of $Q_{10}$-values provided from the literature for comparable environmental conditions (see Sect. 4.4). The average daytime heterotrophic respiration emission of $94 \mathrm{tCO}_{2} \mathrm{ha}^{-1} \mathrm{y}^{-1}$, which covered both open and closed canopy conditions, was used as a reference. The diurnal mean temperatures of the surface peat were found to be lower than daytime temperatures measured during gas flux monitoring. The average difference between daytime and diurnal temperatures was $1.45^{\circ} \mathrm{C}$ across both open and closed canopy conditions inside Acacia plantations. Assuming that a difference in peat temperature of $1{ }^{\circ} \mathrm{C}$ results in a $10 \%$ difference in $\mathrm{CO}_{2}$ emission (op. cit. in Sect. 4.4), the daytime $\mathrm{CO}_{2}$ emission value may therefore be reduced by up to $14.5 \%$ to account for diurnal temperature fluctuation in peat. Applying this correction to the mean daytime $\mathrm{CO}_{2}$ emission value of $94 \mathrm{tha}^{-1} \mathrm{y}^{-1}$ we calculate an average emission value of $80 \mathrm{tha}^{-1} \mathrm{y}^{-1}$ (Fig. 3).

This temperature corrected emission value of $80 \mathrm{tCO}_{2} \mathrm{ha}^{-1} \mathrm{y}^{-1}$, at an average water depth of $0.8 \mathrm{~m}$, is close to the value of $76 \mathrm{tCO}_{2 \mathrm{e}} \mathrm{ha}^{-1} \mathrm{y}^{-1}$ resulting from subsidence and bulk density measurements conducted partly in the same landscape at the same water table depth (Hooijer et al., 2012). It is also close to the values of 72 to $72.8 \mathrm{tCO}_{2 \mathrm{e}} \mathrm{ha}^{-1} \mathrm{y}^{-1}$ suggested by Hooijer et al. (2010) and Couwenberg et al. (2010) in their meta-analyses, for a plantation water depth of $0.8 \mathrm{~m}$. In two other studies, Murdiyarso et al. (2010) and Koh et al. (2011) apply a much lower estimate (34.1 tha $\mathrm{th}^{-1} \mathrm{y}^{-1}$ at $0.5 \mathrm{~m}$ water table depth) for heterotrophic respiration emissions under plantation conditions. This estimate, however, is based on only two case studies (Murayama and Bakar, 1996; Melling et al., 2005) that present very limited datasets at only one or a few locations, and a poor description of measurement method and field conditions.
The adjusted value $\left(80 \mathrm{tCO}_{2 \mathrm{e}} \mathrm{ha}^{-1} \mathrm{y}^{-1}\right)$ is based upon diurnal temperature difference measured near the peat surface, at $5 \mathrm{~cm}$ depth, whereas we found that temperature fluctuation diminished rapidly with increasing depth. Our approach therefore suggests that most peat oxidation, and therefore production of $\mathrm{CO}_{2}$ gas, takes place in the upper $10 \mathrm{~cm}$ of the peat profile. We may assume therefore that oxygen availability is highest at shallowest depth where the near-surface peat layer contains a relatively larger amount of the most labile peat carbon compounds that are substrates for heterotrophic organisms. Consequently, the highest oxidation rate, i.e. heterotrophic respiration emission will take place near to the peat surface. While we have no information on the distribution of $\mathrm{CO}_{2}$ gas production in the peat profile, it is likely that part of it is generated at greater depth and, therefore, the temperature corrected emission value of $80 \mathrm{tha}^{-1} \mathrm{y}^{-1}$ may be seen as a minimum estimate.

In drained forest in Kalimantan, the average of long-term diurnal $\mathrm{CO}_{2}$ emission was $18 \%$ below emissions measured at mid-day (Hirano et al., 2009). A single 24-h $\mathrm{CO}_{2}$ emission monitoring study by Ali et al. (2006) in Jambi also yielded a similar diurnal emission difference of $18 \%$ in selectively logged and drained peatland, and a $13 \%$ difference in an oil palm plot on peat. These three values, with a narrow range of $13 \%$ to $18 \%$ in very different land uses in different parts of Indonesia, are close to the $14.5 \%$ reduction applied in the current study for daytime emission measurements in Acacia plantations.

The high sensitivity of $\mathrm{CO}_{2}$ emissions to peat temperature, and the resulting relative insensitivity to water table depth, implies that bringing up water tables in plantations will not reduce carbon losses by as much as would be expected on the basis of peat surface emissions in forest systems (e.g. Jauhiainen et al., 2005, 2008) or earlier relations between water table depth and $\mathrm{CO}_{2}$ emission (e.g. Couwenberg et al., 2010; Hooijer et al., 2010). The implication of this is that high $\mathrm{CO}_{2}$ emission from any peatland that is converted to agriculture, whatever its water and land management, should be regarded as inevitable.

\subsection{Comparing temperature and water table depth as likely main drivers of heterotrophic $\mathrm{CO}_{2}$ emissions in tropical peatland plantations}

The effect of temperature on average $\mathrm{CO}_{2}$ emission arising from heterotrophic respiration in Acacia plantations can be estimated by applying the same correction factor as used above, of a $1^{\circ} \mathrm{C}$ temperature difference yielding a $10 \%$ difference in $\mathrm{CO}_{2}$ emission, to the average increase of $5.6^{\circ} \mathrm{C}$ after deforestation and drainage that follows from the above analysis of data from Central Kalimantan. This indicates that up to $56 \%$ of the $\mathrm{CO}_{2}$ emission in Acacia plantations may be caused by the change in peat temperature after plantation development alone, which would make it the most important single controlling factor. The remaining $44 \%$ of emission 
can be attributed to reduction in soil moisture content (with water table depth as a proxy), and also to soil disturbance and fertilization. This likely dominance of temperature as a cause of oxidation in tropical peatland plantations has not been given sufficient attention in earlier studies reviewed by Hooijer et al. (2010) and Couwenberg et al. (2010), which focused on the effect of water table depth.

\section{Conclusions}

This study is the largest and most detailed investigation of $\mathrm{CO}_{2}$ emissions undertaken in an industrial plantation on tropical peat. It is also the first study to separate and quantify autotrophic and heterotrophic $\mathrm{CO}_{2}$ emissions. We conclude that the scale of this study, and its consistent approach to separating emission contributions, is necessary in order to determine "net" $\mathrm{CO}_{2}$ emissions from drained tropical peatland. We present a monitoring system that yields reliable and checkable results, but which differs markedly from methods applied in previous studies.

The contribution of autotrophic respiration to $\mathrm{CO}_{2}$ emission was found to be $21 \%$ on average along transects in mature tree stands. Significantly higher autotrophic respiration occurred very close to Acacia trees, but was negligible at distances of more than $1.3 \mathrm{~m}$ from them, indicating that our emission measurements well away from trees were free of any contribution from autotrophic respiration and representated heterotrophic respiration only.

We calculated an average minimum heterotrophic respiration emission rate of $80 \mathrm{tCO}_{2} \mathrm{ha}^{-1} \mathrm{y}^{-1}$ for the Acacia plantation, after reducing the initial average daytime rate of $94 \mathrm{tha}^{-1} \mathrm{y}^{-1}$ by $14.5 \%$ to account for the lower night time peat temperatures. A temperature correction has not been applied before, but we believe it is necessary in order to compare the results of different emission studies more precisely. The resulting value applies at an average water table depth of $0.8 \mathrm{~m}$, in peatland with a thickness greater than $4 \mathrm{~m}$, for a peat surface covered by vegetation and with limited fertilizer applied only in the first year after planting. This value $\left(80 \mathrm{tCO}_{2} \mathrm{ha}^{-1} \mathrm{y}^{-1}\right)$ is supported by the results of a parallel study of carbon loss, carried out at the same location at the same time, of peat subsidence and peat characteristics (bulk density and carbon content) (Hooijer et al., 2012).

Mean long-term water table depth along transects correlates well with average heterotrophic respiration emissions, although the results of our study indicate that temperature differences may be the most important factor controlling peat oxidation and account for over $50 \%$ of heterotrophic $\mathrm{CO}_{2}$ emissions from drained peatlands when compared to forested, pre-clearance conditions. Even if the water table were at the surface, which is impossible in plantations, the relation would predict that $\mathrm{CO}_{2}$ emissions from heterotrophic respiration are $23 \mathrm{tha}^{-1} \mathrm{y}^{-1}$ or more. It is therefore evident that high $\mathrm{CO}_{2}$ emissions are inevitable in any type of agricultural or plantation development on tropical peatland.

There is no reason to assume these conclusions apply only to Acacia plantations. All developments on tropical peatland require removal of forest cover and lowering of the water table. Growing non-permanent crops (e.g. vegetables, rice) on peat results in less ground cover and higher temperatures than in Acacia or oil palm plantations. Most crops, including oil palm, also require much higher fertilizer inputs than Acacia, which will further enhance peat oxidation. Thus emissions from other types of cultivation on peat are likely to be as high or higher than those from Acacia plantations, at similar water depths and on similar peat types.

This study sets a new standard for greenhouse gas flux studies from tropical peatlands under different forms of land management. Our findings indicate that past studies have underestimated peat surface $\mathrm{CO}_{2}$ emissions from peatland plantations, with important implications for the scale of greenhouse gas emissions arising from land use change, particularly in the light of current, rapid agricultural conversion of peatlands in the Southeast Asian region (Miettinen and Liew, 2010).

Acknowledgements. We thank the SDWA and TROPEASS projects for further financial support. Professor Jack Rieley is thanked for helpful comments during paper preparation.

Edited by: D. Zona

\section{References}

Ali, M., Taylor, D., and Inubushi, K.: Effects of environmental variations on $\mathrm{CO}_{2}$ flux from a tropical peatland in eastern Sumatra, Wetlands, 26, 612-618, 2006.

Brady, M. A.: Organic matter dynamics of coastal peat deposits in Sumatra, Indonesia, Ph.D. thesis, University of British Columbia, Vancouver, 258 pp., 1997.

Chimner, R. A. and Ewel, K. C.: Differences in carbon fluxes between forested and cultivated Micronesian tropical peatlands, Wetl. Ecol. Manag., 12, 419-427, 2004.

Couwenberg, J., Dommain, R., and Joosten, H.: Greenhouse gas fluxes from tropical peatlands in southeast Asia, Glob. Change Biol., 16, 1715-1732, 2010.

Edwards, R., Mulligan, D., and Marelli, L.: Indirect land use change from increased biofuels demand, JRC Scientific and Technical Reports, European Union, Italy, doi:10.2788/54137, 2010.

Fargione, J., Hill, J., Tilman, D., Polasky, S. and Hawthorne, P.: Land Clearing and the Biofuel Carbon Debt, Science, 319, 12351238, 2008.

Furukawa, Y., Inubushi, K., Ali, M., Itang, A. M., and Tsuruta, H.: Effect of changing groundwater levels caused by land-use changes on greenhouse gas fluxes from tropical peatlands, Nutr. Cycl. Agroecosys., 71, 81-91, 2005.

Hadi, A., Inubushi, K., Furukawa, Y., Purnomo, E., Rasmadi, M., and Tsuruta, H.: Greenhouse gas emissions from tropical 
peatlands of Kalimantan, Indonesia, Nutr. Cycl. Agroecosys., 71, 73-80, 2005.

Hanson, P. J., Edwards, N. T., Garten, C. T., and Andrews, J. A.: Separating root and soil microbial contributions to soil respiration: A review of methods and observations, Biogeochemistry, 48, 115-146, 2000.

Hergoualch, K. and Verchot, L.V.: Stocks and fluxes of carbon associated with land use change in Southeast Asian tropical peatlands: A review, Global Biogeochem. Cy., 25, GB2001, doi:10.1029/2009GB003718, 2011.

Hirano, T., Jauhiainen, J., Inoue, T., and Takahashi, H.: Controls on the carbon balance of tropical peatlands, Ecosystems, 12, 873887,2009

Hooijer, A., Page, S., Canadell, J. G., Silvius, M., Kwadijk, J., Wösten, H., and Jauhiainen, J.: Current and future $\mathrm{CO}_{2}$ emissions from drained peatlands in Southeast Asia, Biogeosciences, 7, 1505-1514, doi:10.5194/bg-7-1505-2010, 2010.

Hooijer, A., Page, S., Jauhiainen, J., Lee, W. A., Lu, X., Idris, A and Anshari, G.: Peatland subsidence and carbon loss in pulp tree and oil palm plantations in Sumatra, SE Asia: reducing uncertainty and implications for emission reduction options, Biogeosciences, 2012.

Inubushi, K., Furukawa, Y., Hadi, A., Purnomo, E., and Tsuruta, $\mathrm{H}$.: Seasonal changes of $\mathrm{CO}_{2}, \mathrm{CH}_{4}$ and $\mathrm{N}_{2} \mathrm{O}$ fluxes in relation to land-use change in tropical peatlands located in coastal area of South Kalimantan, Chemosphere, 52, 603-608, 2003.

Jauhiainen, J., Takahashi, H., Heikkinen, J. E. P., Martikainen, P. J., and Vasander, H.: Carbon fluxes from a tropical peat swamp forest floor, Global Change Biol., 11, 1788-1797, 2005.

Jauhiainen, J., Limin, S., Silvennoinen, H., and Vasander, H.: Carbon dioxide and methane fluxes in drainage affected tropical peat before and after hydrological restoration, Ecology, 89, 3503$3514,2008$.

Jauhiainen, J., Silvennoinen, H., Hämäläinen, R., Kusin, K., Limin, S., Raison, R.J., and Vasander, H.: Nitrous oxide fluxes from tropical peat with different disturbance history and management, Biogeosciences, 2012.

Jaya, A.: Ecological planning of tropical peatland for carbon and water conservation, Ph.D. thesis, University of Nottingham, United Kingdom, 178 pp., 2007.

Koh, L. P., Miettinen, J., Liew, S. C., and Ghazoul, J.: Remotely sensed evidence of tropical peatland conversion to oil palm, Natl. Acad. Sci. USA, 108, 5127-5132, doi:10.1073/pnas.1018776108, 2011.

Lafleur, P. M., Moore, T. R., Roulet, N. T., and Frolking, S.: Ecosystem respiration in a cool temperate bog depends on peat temperature but not water table, Ecosystems, 8, 619-629, 2005.

Langner, A. and Siegert, F.: Spatiotemporal fire occurrence in Borneo over a period of 10 years, Global Change Biol., 15, 48-62, 2009.

Liyama, I. and Osawa, K.: Surface $\mathrm{O}_{2}$ in flux related to soil $\mathrm{O}_{2}$ profiles in a drained tropical peatland, Soil Sci. Plant Nutr., 56, 517-520, 2010

Mäkiranta, P., Laiho, R., Fritze, H., Hytönen, J., Laine, J., and Minkkinen, K.: Indirect regulation of heterotrophic peat soil respiration by water level via microbial community structure and temperature sensitivity, Soil Biol. Biochem., 41, 695-703, 2009.
Melling, L., Hatano, R., and Goh, K. J.: Soil $\mathrm{CO}_{2}$ flux from three ecosystems in tropical peatland of Sarawak, Malaysia, Tellus B, 57, 1-11, 2005.

Melling, L., Goh, G. J., Beauvais, C., and Hatano, R.: Carbon flow and budget in a young mature oil palm agroecosystem on deep tropical peat, in: Carbon-climate-human interaction on tropical peatland. Proceedings of The International Symposium and Workshop on Tropical Peatland, Yogyakarta, 27-29 August 2007, edited by: Rieley, J. O., Banks, C. J., and Radjagukguk, B., EU CARBOPEAT and RESTORPEAT Partnership, Gadjah Mada University, Indonesia and University of Leicester, United Kingdom, 153-157, 2007.

Miettinen, J. and Liew, S.C.: Degradation and development of peatlands in peninsular Malaysia and in the islands of Sumatra and Borneo, Land Degrad. Dev., 21, 285-296, 2010.

Minkkinen, K., Laine, J., Shurpali, N. J., Mäkiranta, P., Alm, J., and Penttilä, T.: Heterotrophic soil respiration in forestry-drained peatlands, Boreal Environ. Res., 12, 115-126, 2007.

Moore, S., Gauci, V., Evans, C. D., and Page, S. E.: Fluvial organic carbon losses from a Bornean blackwater river, Biogeosciences, 8, 901-909, doi:10.5194/bg-8-901-2011, 2011.

Murayama, S. and Bakar, Z.A.: Decomposition of tropical peat soils, 2. Estimation of in situ decomposition by measurement of $\mathrm{CO}_{2}$ flux, JARQ-Jpn. Agr. Res. Q., 30, 153-158, 1996.

Murdiyarso, D., Hergoualc'h, K., and Verchot, L. V.: Opportunities for reducing greenhouse gas emissions in tropical peatlands, $\mathrm{P}$. Natl. Acad. Sci. USA, 107, 19655-19660, 2010.

Nykänen, H., Alm, J., Lang, K., Silvola, J., and Martikainen, P. J.: Emissions of $\mathrm{CH}_{4}, \mathrm{~N}_{2} \mathrm{O}$ and $\mathrm{CO}_{2}$ from virgin fen and a fen drained for grassland in Finland, J. Biogeogr., 22, 351-357, 1995.

Page, S. E., Hosciło, A., Wösten, H., Jauhiainen, J., Silvius, M., Rieley, J., Ritzema, H., Tansey, K., Graham, L., Vasander, H., and Limin, S.: Restoration ecology of lowland tropical peatlands in Southeast Asia: current knowledge and future research directions, Ecosystems, 12, 888-905, 2009.

Page, S. E., Rieley, J. O., and Banks, C. J.: Global and regional importance of the tropical peatland carbon pool, Global Change Biol., 17, 798-818, 2011.

Rieley, J. O., Wüst, R. A. J., Jauhiainen, J., Page, S. E., Ritzema, H., Wösten, H., Hooijer, A., Siegert, F., Limin, S., Vasander, H., and Stahlhut, M.: Tropical peatlands, carbon stores, carbon gas emissions and contribution to climate change processes, in: Peatlands and Climate Change, edited by: Strack, M., International Peat Society, Jyväskylä, Finland, 148-181, 2008.

Silvola, J., Alm, J., Ahlholm, U., Nykänen, H., and Martikainen, P. $\mathrm{J}$.: $\mathrm{CO}_{2}$ fluxes from peat in boreal mires under varying temperature and moisture conditions, J. Ecol., 84, 219-228, 1996.

Stephens, J. C. and Stewart, E. H.: Effect of climate on organic soil subsidence, in: Proceedings of the 2nd Symposium on land subsidence, Anaheim, California, 1976 IAHS-AIHS Publication No. 121, 647-655, 1977. 